HID光源によるカラーテレビの

色再現汇成する一冢

○小玉宏治川上幸二 藤夫

（岩崎雷気株式会社）

1・はじめに

我々は、「テレビ中継が行われるスボーツ施設などにおいて、カラーテレビの色再現のためには、どの種の光

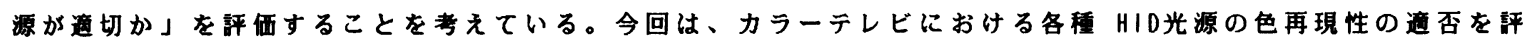
価するために、まず次の 3 点に模討を加えることにした。

(1) 通否の評洒にはどの種類の色を対象とすればよいか。

(2) 道否の評価には $\mathrm{Ra}$ や $\mathrm{Ri}$ が本当に罗当でないのかどうか。

（3）道否の評価は基準（白整電球）の色との色差で表し得るか。

\title{
2. 実弱方法
}

白熱電球（基隼）による咉像と、6 種類のHID光源（表一1） による映像を、男女60名の被锒者に交互に10秒程度ずつ見せ、そ の時のHID光源の映傔について、次の 2 通りの評価をさせた。な お、映像は、(1)朝の食卓、(2)女性の上半身、(3)緑と果実、(4)海水 浴のホスターの 4 カットで、 $3 / 4$ インチ・トリニコンにて録画 した。ホワイトバランスは、各光源毎に調節した。

[評偭A]：色差の評洒（カテコリー；同じ・わずかに䢖う・相 当違う・著しく连う・亟めて著しく䢖う)

[産洒 B]：通否の評洒（カテコリー；使える・どちらともいえ ない・使えない)

さらに、4 種類のカット每に、特に注目していた物（筫所）む 指摘させた。

\section{3.結果と考察}

実駼結果は、各カットにおいて被駼者加注目していたとする物 （色）每に集計し、系列籁ち由う法により「評洒 A」・「評価 B 」の尺度化を图った。さらに、因子分析によって、被政者加注目 していたとする物（色）を分析した（图一1）。

（1）因子分析結果からは、色再現の通否の評価は、「肌色」と 「肌色以外の全般的な色」との組み合わせで評価できると予测で きる。

（2）そこて「肌色」とR 15、「肌色以外の全般的な色」と R a との相閲を吟味したか、 $r=0.70 \sim 0.77$ 程度であった。した 加って、R15と Ra の組み合わせによる評洒では、色再現の通否 を十分に表しえない。

（3）一方、「色再現の道否の評価は、基準（白熱電球）の色と

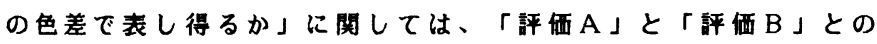
間に $r=0.99$ の良好な相関関係（图一2）加得られたので、色再 現の通否を色差で判断しても良いと言える。しかし、基準光から ある一定の匴囲の色差は、「使える」と判定できるので、「洋価 $\mathrm{A} 」 と 「$ 解価B」との関係は、直線相関にない可能性むある。

4・あとがき

カラーテレビの色再現における光源の通否は、「肌色」と「肌 色以外の色」との組み合わせで評価でき、基準光との色差で拜価 してむよいことが判明した。しかし、Ra と R15による評洒では 、十分であるとはいえないので、本実駼の主钼評価と良く相関す る「色差計算に基づく評洒法」の模討を今後の婹題としたい。 A consideration on color reproduction of color television by HID lamps applied, Kohji Kodama, Kohji Kawakami, Hideo Saitou.

表 -1 試料光源

\begin{tabular}{|c|c|c|c|}
\hline 名 称 & 記 号 & 色温度 & $\mathrm{Ra}$ \\
\hline \multirow{2}{*}{ 水銀ランブ } & $\mathrm{H}$ & $6,000 \mathrm{~K}$ & 20 \\
\cline { 2 - 4 } & $\mathrm{HF}$ & $3,900 \mathrm{~K}$ & 41 \\
\hline \multirow{2}{*}{$\begin{array}{c}\text { メタルハラ } \\
\text { イドランブ }\end{array}$} & $\mathrm{M}(\mathrm{Sc}-\mathrm{Na})$ & $4,400 \mathrm{~K}$ & 61 \\
\cline { 2 - 4 } & $\mathrm{MD}(\mathrm{Dy}-\mathrm{Nd})$ & $6,750 \mathrm{~K}$ & 87 \\
\hline \multirow{2}{*}{$\begin{array}{c}\text { 高圧ナトリ } \\
\text { ウムランブ }\end{array}$} & $\mathrm{NH}$ & $2,050 \mathrm{~K}$ & 21 \\
\cline { 2 - 4 } & $\mathrm{NHDX}$ & $2,500 \mathrm{~K}$ & 84 \\
\hline
\end{tabular}

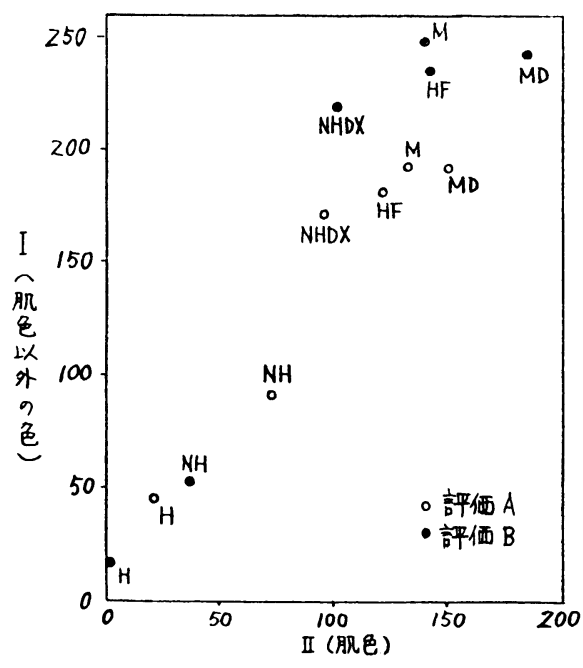

図1.因子得点

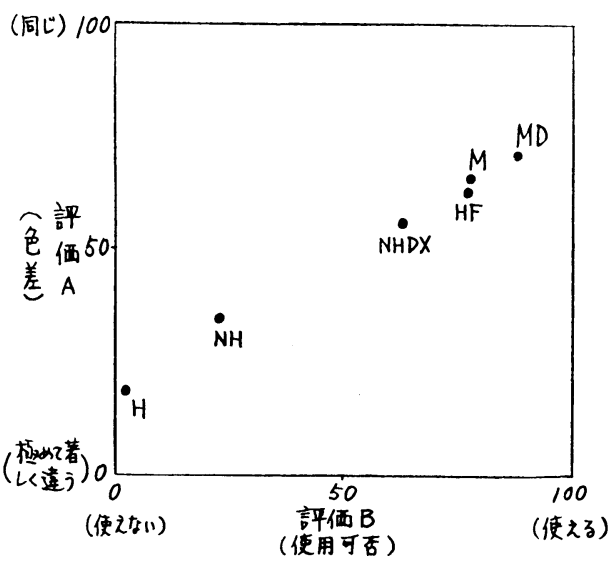

図2.铗価点 